\title{
CITRA TUBUH NEGATIF CENDERUNG MENURUNKAN ASUPAN GIZI PADA REMAJA PEREMPUAN
}

\author{
Alfi Fairuz Asna ${ }^{*}$, A.Fahmi A. Tsani ${ }^{2}$, M.Juffrie ${ }^{3}$ \\ 1. Program Studi S1 Ilmu Gizi, STIKes Mitra Keluarga, Bekasi-Indonesia \\ 2. Program Studi S1 Gizi Kesehatan Universitas Gadjah Mada, Yogyakarta-Indonesia \\ 3. Departemen Anak, RSUP dr. Sardjito, Yogyakarta-Indonesia
}

*Korespondensi: Alfi Fairuz Asna|STIKes Mitra Keluarga | fairuzasna@ gmail.com

\begin{abstract}
Abstrak
Pendahuluan: Remaja adalah periode transisi yang melibatkan perubahan perkembangan fisiologis, psikologis, dan sosial yang dapat menyebabkan kelebihan berat badan dan cenderung menjadi obesitas di masa dewasa. Pada masa remaja ada perubahan fisik, biologis, dan kognitif, cepat dan drastis. Perubahan yang cepat ini membuat respons remaja yang sangat memperhatikan bentuk tubuh mereka dan ingin menurunkan berat badannya. Untuk mengetahui hubungan antara citra tubuh, asupan makanan dan aktivitas fisik di kalangan remaja perempuan.

Metode: Penelitian ini merupakan penelitian observasional dengan rancangan cross sectional, pada 140 siswa SMU di Yogyakarta. Citra tubuh diukur dengan gambar tubuh-34 kuesioner; asupan makanan yang diukur dengan recall 24 jam yang dilakukan selama 3 hari, mewakili hari kerja dan akhir pekan, dan aktivitas fisik yang diukur dengan aktivitas recall.Data dianalisis dengan uji-T.

Hasil: Ada 22,14\% wanita muda yang diketahui mengalami ketidakpuasan dengan citra tubuh. T-test menunjukkan bahwa, ada hubungan yang signifikan antara citra tubuh dan asupan gizi $(\mathrm{p}<0,05)$.
\end{abstract}

Kesimpulan: Ada hubungan yang signifikan secara statistik antara citra tubuh dengan asupan gizi.

Kata Kunci : Citra tubuh, Pengontrolan berat badan, Remaja.

Diterima 23 Oktober 2018; Accepted 30 Desember 2018

\section{PENDAHULUAN}

Kelebihan berat badan dan obesitas adalah masalah kesehatan utama baik di negara maju maupun di negara-negara berkembang. Menurut Survei Kesehatan dan Gizi Nasional (NHANES) 2007-2008 menunjukkan bahwa 16,9\% anak-anak dan remaja berusia 2-19 tahun mengalami obesitas. Remaja gemuk cenderung menjadi obesitas di masa dewasa (Freedman, dkk, 2005) dan memiliki risiko lebih tinggi terhadap masalah kesehatan seperti diabetes, penyakit jantung, stroke, kanker dan osteoartritis (office of the surgeon general, 2010). Menurut data Riskesdas, prevalensi nasional remaja obesitas berusia 16-18 tahun adalah 7,3\% (5,7\% kelebihan berat badan dan obesitas 1,6\%) pada tahun 2013 dan Yogyakarta termasuk di lima belas provinsi dengan prevalensi kelebihan berat badan remaja usia 1618 tahun di atas prevalensi nasional (Depkes,2013). Remaja sering merasa tidak puas dengan citra tubuh, terutama remaja yang kelebihan berat badan dan obesitas dan ingin menurunkan berat badan (Setas, 2009). Citra tubuh memainkan peran penting dalam manajemen berat badan, terutama di kalangan remaja perempuan. Tingginya insidensi ketidakpuasan tubuh pada remaja perempuan dilaporkan berulang kali dalam beberapa penelitian (Pritchard, dkk., 1997 dan Cooper \& Goodyear, 1997). Persepsi diri terhadap berat badan merupakan salah satu faktor yang memotivasi pengendalian berat badan (Desmond, dkk., 2012).

\section{METODE}

Sebuah studi cross sectional dilakukan di SMA di Yogyakarta pada Mei-Juni 2014 di antara 140 mahasiswi. Subjek penelitian dipilih dengan simple random sampling. Subjek yang memenuhi syarat untuk penelitian ini jika berusia 15-18 tahun, bersedia mengikuti penelitian, dan orang tua setuju, terbukti dengan informed consent. Kriteria eksklusi adalah antropometri yang tidak diperbolehkan diukur, menderita penyakit yang membutuhkan diet tertentu, dan kurus. Citra tubuh dinilai dengan menggunakan Body Shape Questionaire 34 (BSQ 34) terdiri dari 34 pertanyaan. Nilai BSQ kurang dari 110 dinyatakan puas sedangkan nilai BSQ lebih besar dari atau sama dengan 100 menunjukkan tidak puas (Tarigan, Hadi, dan Julia., 2005). Asupan zat gizi diukur menggunakan recall 24 jam selama 3 
hari tidak berturut-turut. Uji t-test digunakan untuk menganalisis data.

\section{HASIL}

\section{A. Karakteristik Responden}

Usia rata-rata subjek berusia 16 tahun. $77,86 \%$ subjek merasa puas dengan citra tubuhnya dan $22,14 \%$ tidak puas dengan citra tubuhnya. Hasil ini dapat dilihat di tabel 1.

Tabel 1. Karakteristik Subjek Penelitian

\begin{tabular}{cc}
\hline Karakteristik Dasar & $\mathbf{N = 1 4 0}$ \\
\hline Umur & $16 \pm 0.69$ \\
$($ mean \pm sd) tahun & \\
Citra Tubuh & $109(77.86 \%)$ \\
Puas & $31(22.14 \%)$ \\
Tidak Puas &
\end{tabular}

\section{B. Persepsi Citra Tubuh dan Asupan Gizi}

Tabel 2 menunjukkan bahwa terdapat perbedaan asupan energi pada kelompok remaja dengan persepsi citra tubuh puas dan tidak puas. Remaja dengan persepsi citra tubuh tidak puas cenderung melakukan pengurangan asupan energi.

Tabel 2. Hubungan Citra Tubuh dengan Asupan Energi

\begin{tabular}{cccc}
\hline Kelompok & Mean $\pm \mathbf{s d}$ & $\mathbf{p}$ & $\mathbf{9 5 \%}$ CI \\
\hline Puas & $1213 \pm 301.46$ & 0.02 & $1155.88-1270.35$ \\
Tidak puas & $1069 \pm 314.78$ & & $954.38-1185.31$ \\
\hline
\end{tabular}

Tabel 3 menunjukkan perbedaan asupan karbohidrat pada kelompok dengan persepsi citra tubuh puas dan tidak puas. Pada kelompok dengan citra tubuh tidak puas cenderung mengurangi asupan karbohidrat.

Tabel 3. Hubungan Citra Tubuh dengan Asupan Karbohidrat

\begin{tabular}{cccc}
\hline Kelompok & Mean \pm sd & p & 95\% CI \\
\hline Puas & $156.24 \pm 44.49$ & 0.02 & $147.79-164.69$ \\
Tidak puas & $134.96 \pm 51.21$ & & $116.17-153.74$ \\
\hline
\end{tabular}

Tabel 4 dan tabel 5 menunjukkan perbedaan asupan protein dan lemak pada kelompok puas dan tidak puas. Asupan protein dan lemak tidak berbeda signifikan ( $p>0.05)$ pada kelompok remaja dengan persepsi citra tubuh puas maupun tidak puas.

Tabel 4. Hubungan Citra Tubuh dengan Asupan Protein

\begin{tabular}{cccc}
\hline Kelompok & Mean \pm sd & p & 95\% CI \\
\hline Puas & $41.9 \pm 15.49$ & 0.29 & $39.05-44.93$ \\
Tidak puas & $38.79 \pm 12.19$ & & $34.32-43.26$ \\
\hline
\end{tabular}

Tabel 5. Hubungan Citra Tubuh dengan Asupan Lemak

\begin{tabular}{cccc}
\hline Kelompok & Mean \pm sd & $\mathbf{p}$ & $\mathbf{9 5 \%}$ CI \\
\hline Puas & $50.99 \pm 18.90$ & 0.79 & $47.40-54.59$ \\
Tidak puas & $49.91 \pm 23.75$ & & $41.2-58.62$ \\
\hline
\end{tabular}

\section{PEMBAHASAN}

Hasil yang diperoleh dalam penelitian ini menunjukkan ada perbedaan antara persepsi citra tubuh puas dan tidak puas dengan asupan gizi. Hal ini dapat dilihat dari asupan energi dan karbohidrat $(\mathrm{p}<0.05)$. Kelompok yang tidak puas terhadap citra tubuhnya cenderung melakukan pengurangan asupan energi dan karbohidrat. Rerata asupan energi pada kelompok yang puas adalah 1213 kkal dan rerata asupan energi pada kelompok yang tidak puas adalah 1069 kkal. Hasil yang sama juga 
ditunjukkan oleh Ellis dan Colings (1997) dimana gambaran tubuh yang ideal merupakan keinginan setiap remaja. Banyak remaja yang berusaha merubah penampilannya agar terlihat menarik.Perhatian terhadap penampilan dan gambaran tubuh yang ideal dapat mengarah kepada upaya mengontrol berat badan. Pada tabel 4 dan 5 rerata asupan protein dan lemak pada kelompok dengan persepsi citra tubuh puas tidak berbeda signifikan dengan kelompok dengan persepsi citra tubuh tidak puas. Dari hasil tabel 2, menunjukkan bahwa asupan energi remaja putri usia 15-1 tahun masih sangat kurang jika dibandingkan dengan AKG. AKG remaja usia 15- 18 tahun yaitu energi 2125 kal, protein 59 gr, lemak 71 gr, dan karbohidrat 292 gr. Asupan yang tidak adekuat dapat mengakibatkan kekurangan zat gizi esensial bagi pertumbuhan tubuhnya. Akibat dari asupan yang tidak adekuat yaitu anemia, kurang energi kronis yang selanjutnya dapat berakibat pada BBLR. Oleh karena itu perlu diberikan pendidikan gizi mengenai angka kecukupan gizi sesuai dengan usia remaja. Citra tubuh mungkin memainkan peran kunci dalam pembentukan pola perilaku dan kesenjangan antara citra tubuh actual dan ideal dapat berpotensi menyebabkan perilaku diet yang disebabkan oleh ketidakpuasan tubuh.

\section{KESIMPULAN}

Ada perbedaan asupan energi dan karbohidrat pada remaja dengan persepsi citra tubuh puas dan tidak puas. Tidak ada perbedaan asupan protein dan lemak pada remaja dengan persepsi citra tubuh puas maupun tidak puas. Saran untuk penelitian selanjutnya yakni memberikan informasi yang tepat kepada siswa, orangtua dan wali untuk membantu mereka dalam membina citra tubuh yang positif di rumah. Keluarga dan sekolah merupakan tempat untuk memberikan pendidikan bagi remaja sehingga orangtua dan guru diharapkan dapat memberi dukungan, pengaruh positif, serta bimbingan kepada remaja mengenai perkembangan psikologis.

\section{REFERENSI}

Cooper, P.J., dan Goodyear, I. (1997) Prevalence and significance of weight and shape concerns in girls aged 11-16 years. Brit J Psychiat 171:542-544

Desmond S.M., Price J.H., Gray N, dan O'Connell J.K. (1986) The etiology of adolescents' perception of their weight. J Youth Adolesc. 15:6:461-74 dalam Agrawal, Praween., Gupta, Kamla., Mishra, Vinol., dan Agrawal, Sutapa. (2012) A study on body-weight perception, future intention and weight-management behaviour among normal-weight, overweight and obese women in india. Public Health Nutrition. 1-12

Ellis, P.M dan Collings, C.D. (1997) Mental health in New Zealand from a public health perpective. Public Health Report Wellington

Freedman D.S., Kettel L, Serdula M.K., Dietz W.H., Srinivasan S.R., dan Berenson G.S. (2005) The relation of childhood BMI to adult adiposity: the Bogalusa Heart Study. Pediatric. 115:22-27

Kementrian Kesehatan RI. (2013) Riset Kesehatan Dasar Tahun 2013. Jakarta : Balai Penelitian dan Pengembangan Kesehatan Kemenkes RI

Office of the Surgeon General. (2010) The Surgeon General's Vision for a Healthy and Fit Nation. Rockville, MD, U.S. Department of Health and Human Services

Pritchard M.E, King S.L dan Czajka-Narins D.M. (1997) Adolescents body mass indices and selfperception. Adolescence 32:128: 863-880

Setas, Cristina. Perceived Body Image, Obesity and Food Intake in 13-Years Old Adolescent. (2009) Thesis. Universidade do Porto

Tarigan, N., Hadi, H., dan Julia, M. (2005) Hubungan citra tubuh dengan status obesitas, aktivitas fisik, dan asupan energi remaja SLTP di Kota Yogyakarta dan Kabupaten Bantul. Jurnal Gizi Klinik Indonesia. 1:3:130-136 